Etikonomi

Volume 14 (1), April 2015

P-ISSN: 1412-8969; E-ISSN: 2461-0771

Halaman $69-86$

\title{
PENGARUH REKENING DORMANT DAN DANA PIHAK KETIGA (DPK) TERHADAP LABA BANK DI BANK SYARIAH MANDIRI
}

\author{
Khoirunnisa \\ Universitas Muhammadiyah Prof. Dr. Hamka \\ icha.greennymph@gmail.com
}

\begin{abstract}
.
The purpose of this research is to analyze the effect's dormant accounts and the amount of third party funds (DPK) to the bank's profit in Bank of Sharia Mandiri. The analysis of the data used in this research is a method of multiple linear regression with the dependent variable is profit and the independent variables are dormant account and third party funds. The result shows that the dormant account didn't have an effect on bank's profit. Otherwise, the third party funds/deposit funds has an effect of bank's profit. This result imply that bank should reduce the dormant account, if there is a decreasing in dormant account there will be an increasing too in third party funds, and if the third party funds is increasing the bank's profit will be also increasing.
\end{abstract}

Keywords: dormant accounts; third party funds; profits; regression.

\begin{abstract}
Abstrak.
Penelitian dilakukan untuk menganalisis pengaruh rekening dormant dan jumlah dana pihak ketiga (DPK) terhadap laba bank di Bank Syariah Mandiri. Penelitian menggunakan metode regresi linear berganda dengan variabel terikat adalah tingkat keuntungan dan variabel bebas ialah rekening dormant dan dana pihak ketiga. Hasil penelitian menunjukkan bahwa rekening dormant tidak memiliki pengaruh terhadap tingkat keuntungan bank. Sedangkan, dana pihak ketiga memiliki pengaruh terhadap tingkat keuntungan bank. Hasil ini berimplikasi bahwa bank sebaiknya menurunkan jumlah rekening dormant, penurunan rekening dormant akan menaikkan dana pihak ketiga, dan pada akhirnya kenaikan dana pihak ketiga ini akan mampu menaikkan tingkat keuntungan bank.
\end{abstract}

Kata Kunci: rekening dormant; dana pihak ketiga; laba; regresi berganda.

Diterima: 26 Januari 2015; Direvisi: 5 Maret 2015; Disetujui: 10 Maret 2015 


\section{PENDAHULUAN}

Persaingan bank dalam memperebutkan nasabah di Indonesia sangat ketat, sehingga banyak bank-bank syariah didirikan. Dengan jumlah bank dan kantor cabang yang masih tetap banyak dan produk yang ditawarkan bank beragam, lalu terbatasnya sumber daya manusia yang profesional, teknologi informasi dan telekomunikasi yang terus berkembang, serta peningkatan harga bahan pangan menjadi hambatan besar bagi bank pemerintah dalam mengakomodasi dana masyarakat. Hal ini menjelaskan bahwa perbankan syariah telah memberikan pengaruh yang signifikan pada praktik keuangan syariah.

Tabel 1. Perkembangan Kelembagaan Perbankan Syariah

\begin{tabular}{lccccccccc}
\hline & 2006 & 2007 & 2008 & 2009 & 2010 & 2011 & 2012 & 2013 & 2014 \\
\cline { 2 - 10 } Bank Umum Syariah & 3 & 3 & 5 & 6 & 11 & 11 & 11 & 11 & 12 \\
Unit Usaha Syariah & 20 & 26 & 27 & 25 & 23 & 24 & 24 & 23 & 22 \\
\hline
\end{tabular}

Sumber: Statistik Perbankan Syariah, 2015 (data diolah).

Berdasarkan Tabel 1 terlihat bahwa perkembangan Bank Umum Syariah semakin meningkat. Pada tahun 2009 terlihat jelas hanya ada 6 Bank Umum Syariah (BUS) yang beroperasi di Indonesia dan tahun berikutnya mengalami peningkatan yaitu 11 Bank Umum Syariah (BUS), sehingga menjadi kabar gembira untuk dunia perbankan syariah. Perkembangan perbankan syariah dapat dilakukan melalui enam tahap, yaitu: Pertama, penetapan beroperasinya lembaga keuangan Islam; Kedua, untuk mengembangkan strategi operasi bank yang paling baik, dilakukan riset adopsi dan harapan nasabah; Ketiga, penetapan standar prosedur operasional; Keempat, bank konvensional diajak untuk menawarkan produk dan jasa keuangan Islam; Kelima, pengintegrasian para pemain lembaga keuangan internasional; Keenam, melakukan kegiatan pemasaran yang terencana dalam berbagai skala untuk menjangkau seluruh lapisan masyarakat. 
Tabel 2. Perkembangan DPK, Pembiayaan, dan Aset Perbankan (miliar rupiah)

\begin{tabular}{lrrrrrrr}
\hline & \multicolumn{1}{c}{$\mathbf{2 0 0 8}$} & \multicolumn{1}{c}{$\mathbf{2 0 0 9}$} & \multicolumn{1}{c|}{$\mathbf{1 0 1 0}$} & \multicolumn{1}{c}{$\mathbf{2 0 1 1}$} & \multicolumn{1}{c|}{$\mathbf{2 0 1 2}$} & \multicolumn{1}{c}{$\mathbf{2 0 1 3}$} & \multicolumn{1}{c}{$\mathbf{2 0 1 4}$} \\
\hline DPK & 36,852 & 52,271 & 76,036 & 115,415 & 147,512 & 174,018 & 186,608 \\
Pertumbuhan (\%) & 31.56 & 41.84 & 45.46 & 51.80 & 27.81 & 17.97 & 7.23 \\
Pembiayaan & 38,194 & 46,886 & 68,181 & 102,655 & 147,505 & 179,284 & 187,886 \\
Pertumbuhan (\%) & 36.68 & 22.76 & 45.42 & 50.56 & 43.69 & 21.54 & 4.80 \\
Aset & 49,555 & 66,090 & 97,519 & 145,467 & 195,018 & 229,557 & 244,197 \\
Pertumbuhan (\%) & 35.63 & 33.37 & 47.55 & 49.17 & 34.06 & 17.71 & 6.38 \\
\hline
\end{tabular}

Sumber: Statistik Perbankan Syariah, Bank Indonesia

Tabel 2 memperlihatkan perkembangan penghimpunan dana pihak ketiga, penyaluran pembiayaan dan aset di industri perbankan nasional baik perbankan konvensional maupun perbankan syariah mulai tahun 2008 sampai dengan 2014. Data memperlihatkan bahwa secara nominal baik dari nilai aset, jumlah penghimpunan dana pihak ketiga, maupun jumlah penyaluran pembiayaan di industri perbankan nasional baik konvensional maupun syariah selalu meningkat. Akan tetapi jika dilihat secara pertumbuhan menunjukkan terjadi penurunan pertumbuhan baik di dana pihak ketiga, pembiayaan, maupun aset mulai dari tahun 2012. Bahkan pada tahun 2014 ini terjadi penurunan pertumbuhan yang drastis pada dana pihak ketiga, penyaluran pembiayaan, dan aset di industri perbankan syariah yaitu di bawah $8 \%$. Penurunan pertumbuhan pun sebenarnya muncul pula di industri perbankan konvensional, namun penurunan pertumbuhan yang terjadi di industri perbankan konvensional tidak menurun drastis sebagaimana yang terjadi pada industri perbankan syariah.

Bank Syariah Mandiri atau yang lebih dikenal dengan sebutan BSM hadir, tampil dan tumbuh sebagai bank yang mampu memadukan idealisme usaha dengan nilai-nilai rohani, yang melandasi kegiatan operasionalnya. Bank syariah merupakan lembaga keuangan syariah yang berorientasi pada laba. Laba bukan hanya untuk kepentingan pemilik atau pendiri, tetapi juga sangat penting untuk pengembangan usaha bank syariah. Laba bank syariah terutama diperoleh dari selisih antara pendapatan atas penanaman dana dan biaya yang dikeluarkan selama periode tertentu. Untuk dapat memperoleh hasil yang optimal, bank syariah dituntut untuk melakukan pengelolaan dananya secara 
efisien dan efektif, baik atas dana yang dikumpulkan dari masyarakat yaitu dana pihak ketiga, serta dana modal pemilik atau pendiri bank syariah maupun atas pemanfaatan atau penanaman dana tersebut.

\section{Gambar 1. Laba dan Jumlah Dana Pihak Ketiga (DPK) 2012-2014}

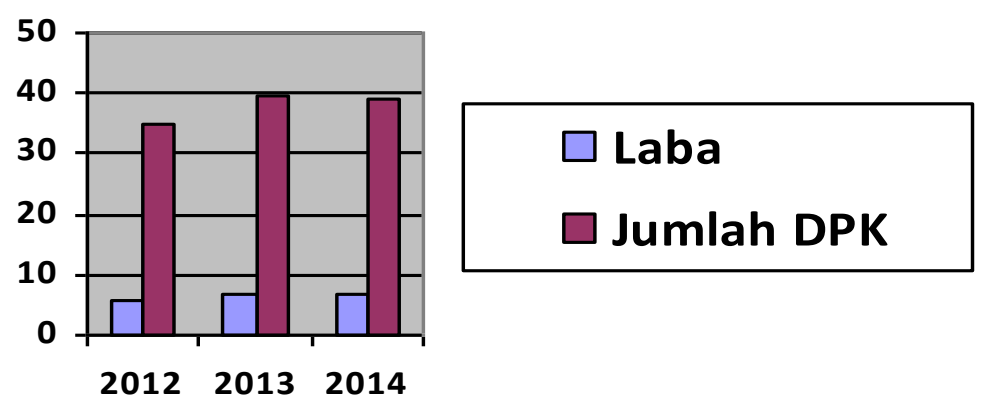

Sumber: BSM Thamrin, 2015 (data diolah).

Pada Gambar 1 menjelaskan bahwa laba bank dan dana pihak ketiga (DPK) dari tahun 2012-2014 mengalami pasang surut. Laba bank tahun 2013 meningkat 13,87\% atau Rp 808 milyar dari 5,823 triliun tahun 2012 ke Rp 6,631 triliun tahun 2013, laba bank tahun 2014 mengalami penurunan 1,2\% atau Rp 82 milyar dari 6,631 triliun tahun 2013 ke Rp 6,549 milyar tahun 2014. Dan jumlah dana pihak ketiga (DPK) tahun 2013 meningkat 15\% atau Rp 5,148 triliun dari 34,636 triliun tahun 2012 ke Rp 39,784 triliun tahun 2013, jumlah dana pihak ketiga (DPK) tahun 2014 mengalami penurunan 1,7\% atau Rp 683 milyar dari 39,784 triliun tahun 2013 ke Rp 39,101 triliun tahun 2014.

Rekening dormant merupakan rekening yang tidak ada aktivitas transaksi (mutasi) selama jangka waktu ( 6 bulan berturut-turut) sejak transaksi terakhir, dimana rekening tersebut akan berubah secara otomatis statusnya dari aktif menjadi tidak aktif (pasif) atau dormant. Menurut Fitri dan Yulianti (2012), rekening pasif (dormant account) berasal dari kata dormant yang berarti terhenti, tidak aktif, tidur, dan kata account yang berarti catatan, uang, rekening. Bila didefinisikan secara lengkap rekening dormant dapat berarti akun tabungan/giro yang tidak menunjukkan mutasi yang aktif, kecuali pencatatan pendapatan bunga/margin pada jangka waktu tertentu, biasanya 
saldo tabungan/giro ini kecil dan setiap bulan dibebani biaya jasa dalam jumlah tertentu atau sama dengan akun tidur. Berikut ini perbandingan rekening tabungan pasif dan aktif.

Tabel 3. Perbandingan Rekening Tabungan Pasif dan Aktif Periode 31 Desember

\begin{tabular}{cccccc}
\hline Periode & Rek Pasif & Rek Aktif & $\begin{array}{c}\text { Jumlah } \\
\text { Rekening }\end{array}$ & \multicolumn{2}{c}{$\begin{array}{c}\text { Perbandingan terhadap Jumlah } \\
\text { Rekening (\%) } \\
\end{array}$} \\
& & & & Rek Pasif & Rek Aktif \\
\hline Des 2012 & 39.662 & 4.115 .970 & 4.155 .632 & $1,0 \%$ & $99,0 \%$ \\
Des 2013 & 1.338 .001 & 4.448 .205 & 5.786 .206 & $23,1 \%$ & $76,9 \%$ \\
Des 2014 & 2.229 .572 & 3.034 .023 & 5.263 .595 & $42,4 \%$ & $57,6 \%$ \\
\hline
\end{tabular}

Sumber: Bank Syariah Mandiri Thamrin, 2015 (data diolah).

Diperlukan suatu strategi pemasaran agar tidak terjadi rekening dormant terhadap nasabah. Salah satu strategi yang dapat dijalankan perusahaan dengan promosi yang merupakan salah satu variabel yang penting dalam pemasaran. Menurut Michael Ray, promosi adalah "the coordination of all seller-iniated efforts to setup channels of information and persuasion to sell goods and services or promote an idea" (koordinasi seluruh upaya yang dimulai pihak penjualan untuk membangun berbagai saluran informasi dan persuasi untuk menjual barang dan jasa atau memperkenalkan suatu gagasan). Masalah pada latar belakang penulisan ini, berdasarkan tabel perbandingan rekening tabungan pasif dan aktif yaitu presentase rekening dormant tiap tahunnya mengalami peningkatan.

Rekening pasif yang semakin meningkat berpotensi menurunkan jumlah dana pihak ketiga, karena menurunnya tingkat loyalitas nasabah. Penurunan tingkat loyalitas nasabah dalam jangka panjang akan berpotensi pada semakin menurunnya jumlah keuntungan dari suatu bank. Oleh karena itu penelitian ini menarik untuk diteliti, dikarenakan jumlah rekening pasif yang semakin meningkat.

\section{METODE}

Objek dalam penelitian ini pada PT. Bank Syariah Mandiri (BSM) Kantor Pusat yang beralamat di Jl. M. H. Thamrin No 5, Jakarta 10340. Telp. (021) 2300509, 39839000. Faks (021) 39832989. Adapun variabel dalam 
penelitian ini yaitu variabel bebas $\left(\mathrm{X}_{1}=\right.$ jumlah rekening dormant; dan $\mathrm{X}_{2}=$ dana pihak ketiga (DPK)) dan variabel terikat ( $\mathrm{Y}=$ laba bank).

Penelitian ini menggunakan metode kuantitatif diskrit. Metode kuantitatif pada umumnya data yang berbentuk angka atau bilangan. Sesuai dengan bentuknya, data kuantitatif dapat diolah atau dianalisis menggunakan teknik perhitungan matematika atau statistika. Metode kuantitatif diskrit yaitu metodologi penelitian yang menganalisis data dalam bentuk bilangan bulat yang diperoleh dengan cara membilang.

Pengumpulan data merupakan proses pengumpulan data primer dan sekunder. Pengumpulan data merupakan langkah yang penting, karena data yang dikumpulkan akan digunakan sebagai pemecah masalah yang sedang diteliti. Metode pengumpulan data kuantitatif yang dilakukan penulis yaitu dengan pengumpulan data sekunder.

Teknik analisis yang dipergunakan dalam penelitian ini adalah regresi linier berganda. Adapun persamaan matematis dalam penelitian ini adalah:

$Y_{t}=\alpha+\beta_{1} X_{1 t}+\beta_{2} X_{2 t}+\varepsilon_{t}$

Dimana:

$\mathrm{Y}_{\mathrm{t}} \quad=$ tingkat keuntungan BSM pada periode $\mathrm{t}$

$\mathrm{X}_{1 \mathrm{t}} \quad=$ jumlah rekening dormant BSM pada periode $\mathrm{t}$

$\mathrm{X}_{2 \mathrm{t}} \quad$ = dana pihak ketiga BSM pada periode $\mathrm{t}$

$\beta_{1}, \beta_{2}=$ koefisien

Regresi linier berganda diatas kemudian diikuti dengan pengujian asumsi klasik, dimana meliputi uji multikoliniearitas, uji autokorelasi, dan uji heterokedastisitas. Uji multikolinearitas adalah untuk melihat ada atau tidaknya korelasi yang tinggi antara variabel-variabel bebas dalam suatu model regresi linear berganda. Jika ada korelasi yang tinggi di antara variabel-variabel bebasnya, maka hubungan antara variabel bebas terhadap variabel terikatnya menjadi terganggu.

Uji heteroskedastisitas adalah untuk melihat apakah terdapat ketidaksamaan varians dari residual satu ke pengamatan ke pengamatan yang 
lain. Model regresi yang memenuhi persyaratan adalah di mana terdapat kesamaan varians dari residual satu pengamatan ke pengamatan yang lain tetap atau disebut homoskedastisitas. Uji autokorelasi adalah untuk melihat apakah terjadi korelasi antara suatu periode $\mathrm{t}$ dengan periode sebelumnya (t-1). Secara sederhana adalah bahwa analisis regresi adalah untuk melihat pengaruh antara variabel bebas terhadap variabel terikat, jadi tidak boleh ada korelasi antara observasi dengan data observasi sebelumnya.

Setelah itu dilanjutkan dengan pengujian hipotesis, yaitu uji t, uji F, dan koefisien determinasi $\left(\mathrm{R}^{2}\right)$. Uji t digunakan untuk mengetahui apakah variabelvariabel independen secara parsial berpengaruh nyata atau tidak terhadap variabel dependen. Derajat signifikansi yang digunakan adalah 0,05. Apabila nilai signifikan lebih kecil dari derajat kepercayaan maka kita menerima hipotesis alternatif, yang menyatakan bahwa suatu variabel independen secara parsial mempengaruhi variabel dependen.

Uji F digunakan untuk mengetahui apakah variabel-variabel independen secara simultan berpengaruh signifikan terhadap variabel dependen. Derajat kepercayaan yang digunakan adalah 0,05. Apabila nilai $\mathrm{F}$ hasil perhitungan lebih besar daripada nilai $\mathrm{F}$ menurut tabel maka hipotesis alternatif, yang menyatakan bahwa semua variabel independen secara simultan berpengaruh signifikan terhadap variabel dependen. Koefisien determinasi digunakan untuk mengetahui seberapa besar hubungan dari beberapa variabel dalam pengertian yang lebih jelas. Koefisien determinasi akan menjelaskan seberapa besar perubahan atau variasi suatu variabel bisa dijelaskan oleh perubahan atau variasi pada variabel yang lain. Nilai koefisien ini antara 0 dan 1, jika hasil lebih mendekati angka 0 berarti kemampuan variabel-variabel independen dalam menjelaskan variasi variabel amat terbatas. Tapi jika hasil mendekati angka 1 berarti variabel-variabel independen memberikan hampir semua informasi yang dibutuhkan untuk memprediksi variasi variabel dependen. 


\section{PEMBAHASAN}

Penelitian ini menggunakan 40 data dari bulan Januari 2012-April 2015. Data yang diperoleh penulis dari laporan publikasi bulanan yang memiliki jangka waktu yang sama. Penulis memperoleh data-data rekening dormant sebagai variabel $\mathrm{X}_{1}$, dana pihak ketiga (DPK) sebagai variabel $\mathrm{X}_{2}$ dan jumlah keuntungan sebagai variabel Y.

Multikoliniearitas adalah keadaan dimana terjadi hubungan linear yang sempurna atau mendekati sempurna antar variabel independen dalam model regresi. Model regresi yang baik adalah yang bebas dari masalah multikoliniearitas.

\section{Tabel 4. Uji Multikolinieritas}

\begin{tabular}{llr}
\hline & \multicolumn{2}{c}{ Collinearity Statistics } \\
Model & Tolerance & VIF \\
\hline 1 (Constant) & & \\
$\quad$ Rekening.Dormant & .767 & 1.304 \\
$\quad$ DPK & .767 & 1.304 \\
a. Dependent Variable: Laba & & \\
\hline
\end{tabular}

Pada Tabel 4 terlihat bahwa nilai VIF Rekening Dormant $1.304<$ 10 dan tolerance Rekening Dormant $0.767>0.1$, maka tidak ada masalah multikoliniearitas antara Rekening Dormant terhadap Laba. Pada tabel tersebut juga menunjukkan nilai VIF Dana Pihak Ketiga (DPK) $1.304<$ 10 dan tolerance Dana Pihak Ketiga (DPK) $0.767>0.1$ maka tidak ada masalah multikoliniearitas antara Dana Pihak Ketiga (DPK) terhadap Laba.

Uji autokorelasi bertujuan untuk menguji apakah dalam sebuah regresi linear terdapat korelasi antara kesalahan pengganggu pada periode $\mathrm{t}$ dengan kesalahan pengganggu pada periode $\mathrm{t}-1$ sebelumnya. Metode pengujian yang sering digunakan adalah uji Durbin-Watson (uji DW). 


\section{Tabel 5. Uji Autokorelasi}

\begin{tabular}{lc}
\hline \multicolumn{1}{c}{ Model } & Durbin-Watson \\
\hline 1 & 1.838 \\
a. Predictors: (Constant), DPK, Rekening.Dormant & \\
b. Dependent Variable: Laba &
\end{tabular}

Keterangan:

$\mathrm{K}=2$ variabel independent (Rekening Dormant dan DPK)

$\mathrm{N}=40$ data

$\mathrm{Dw}=1.838$

$\mathrm{Dl}=1.3908\{(4-\mathrm{d} 1) \cdot 3908=2.6092\}$

$\mathrm{Du}=1.6000\{(4-\mathrm{du}) 4-1.6000=2.4\}$

a $=5 \%$ (Data diolah)

Dapat disimpulkan bahwa keberadaan dw berada pada posisi du dan 4du yang artinya tidak ada autokorelasi. Model regresi ini dikatakan baik jika terhindar dari autokorelasi.

Tabel 6. Hasil Estimasi Regresi Linear Berganda

\begin{tabular}{lcccc}
\hline & \multicolumn{2}{c}{ Unstandardized } & $\mathrm{t}$ & sig \\
\multicolumn{1}{c}{ Coefficients } & & \\
\hline 1 (Constant) & $\mathrm{B}$ & Std. Error & & .000 \\
Rekening Dormant & 11.984 & .062 & 192.780 & .178 \\
DPK & .022 & .016 & 1.374 & .031 \\
\hline
\end{tabular}

a. Dependent Variable: Laba

Uji heteroskedastisitas bertujuan untuk menguji apakah dalam sebuah model regresi terjadi ketidaksamaan varians dari satu pengamatan ke pengamatan yang lainnya. Metode pengujian model regresi ini dapat dilihat menggunakan scatterplot. Jika tidak ada pola lain, seperti titik-itik menyebar di atas dan di bawah angka 0 pada sumbu $Y$, maka tidak terjadi heteroskedastisitas. Setelah melakukan uji asumsi klasik dan hasil output menunjukkan bahwa uji Asumsi Klasik memenuhi persyaratan untuk melakukan uji Regresi Linear Berganda. 
Analisis regresi linear berganda digunakan untuk menguji atau memprediksi apakah variable (X1) Rekening Dormant dan (X2) Dana Pihak Ketiga (DPK) berpengaruh terhadap variabel (Y) laba dan seberapa besar pengaruhnya kedua variabel bebas.

Persamaan regresinya sebagai berikut:

$$
\mathrm{Y}=11.984+0.022 \mathrm{X}_{1}+0.012 \mathrm{X}_{2}
$$

Persamaan regresi tersebut dapat dijelaskan sebagai berikut:

a. Konstanta 11.984 artinya jika Rekening Dormant (X1) dan Dana Pihak Ketiga (X2) nilainya adalah 0 , maka laba (Y) nilainya mengalami penurunan sebesar 11.984 .

b. Koefesien regresi variabel Rekening Dormant (X1) sebesar 0.022 artinya jika variabel independen lain nilainya tetap dan Rekening Dormant mengalami kenaikan 1\% maka laba (Y') akan mengalami kenaikan sebesar 0.022 . Koefesien bernilai positif artinya terjadi hubungan yang positif antara Rekening Dormant dengan Laba, semakin naik Rekening Dormant maka Laba mengalami peningkatan.

c. Koefesien regresi variabel Dana Pihak Ketiga (X2) sebesar 0.012 artinya jika variabel independen lain nilainya tetap dan DPK mengalami kenaikan 1\% maka laba akan mengalami peningkatan sebesar 0.012 Koefesien bernilai positif artinya terjadi hubungan yang positif antara DPK dengan Laba, semakin naik Dana Pihak Ketiga (DPK) maka Laba mengalami peningkatan.

Uji t digunakan untuk mengetahui atau menguji secara parsial masing masing variabel (Rekening Dormant dan Dana Pihak Ketiga) independen berpengaruh nyata atau tidak terhadap variabel dependen (laba). Derajat signifikansi yang digunakan adalah 0,05. Apabila nilai signifikan lebih kecil dari derajat kepercayaan maka kita menerima hipotesis alternatif, yang menyatakan bahwa suatu variabel independen (Rekening Dormant dan Dana Pihak Ketiga) secara parsial mempengaruhi variabel dependen (laba).

Uji statistik t-hitung menunjukkan:

a. Pengaruh Rekening Dormant (X1) terhadap Laba (Y) 
Pada Tabel 6 rekening dormant memiliki nilai thitung 1.374 sehingga, $t_{\text {hitung }}<$ $t_{\text {tabel }}(1.374<2.026)$ maka Ho diterima atau tidak terdapat pengaruh Rekening Dormant terhadap variabel terikat Laba. Selain dari $t_{\text {tabel }}$ tersebut dapat dilihat besar probability value dengan tingkat (sig) Rekening Dormant 0.178 dan nilai $\alpha$ (derajat signifkansi) 0.05 artinya $0.178>0.05$ atau tidak terdapat pengaruh yang signifikan Rekening Dormant terhadap variabel terikat Laba.

b. Pengaruh Dana Pihak Ketiga (X2) terhadap terhadap Laba (Y)

Pada Tabel 6 dana pihak ketiga (DPK) memiliki nilai thitung 2.244 sehingga $t_{\text {hitung }}>t_{\text {tabel }}(2.244>2.026)$ maka Ha diterima atau terdapat pengaruh antara Dana Pihak Ketiga (DPK) terhadap variabel terikat Laba. Selain dari ttabel tersebut dapat dilihat besar probability value dengan tingkat (sig) DPK 0.031 pada tabel Coefficients ${ }^{a}$ dan nilai $\alpha$ (derajat signifkansi) 0.05 artinya $0.031<$ 0.05 atau terdapat pengaruh yang signifikan antara Dana Pihak Ketiga (DPK) terhadap variabel terikat Laba.

Uji F untuk melihat bagaimanakah pengaruh semua variabel bebasnya secara bersama-sama terhadap variabel terikatnya. Berdasarkan tabel anova Uji F menunjukan bahwa nilai $F_{\text {hitung }}$ sebesar 3.572. Nilai $F_{\text {tabel }}$ yang diperoleh yaitu 3,252. Sehingga $F_{\text {hitung }}>F_{\text {tabel }}(3.572>3.252)$ maka HO ditolak. "Hal tersebut membuktikan bahwa terdapat pengaruh antara Rekening Dormant dan Dana Pihak Ketiga (DPK) terhadap Laba. Selain itu dari tabel tersebut dapat dilihat besar probability value dengan tingkat (sig) yaitu 0,009 pada tabel Coefficientsa dengan nilai $\alpha$ (derajat signifkansi) 0.05 yang bearti lebih kecil dari tingkat signifikansi $(0,009<0,05)$ "Hal tersebut membuktikan bahwa terdapat pengaruh signifikan atau secara simultan (bersamasama) antara Rek Dormant dan Dana Pihak Ketiga (DPK) terhadap Laba.

Berdasarkan Tabel 6 tersebut diperoleh angka $\mathrm{R}$ 0.349. Hal ini menunjukkan bahwa terjadi hubungan yang rendah antara Rekening Dormant dan Dana Pihak Ketiga (DPK) terhadap Laba. Nilai R menunjukkan 34.9\% dari dua variabel independen (Rekening Dormant dan Dana Pihak Ketiga) terhadap 
laba. Uji determinasi menunjukan nilai adjusted R-Squared sebesar 0.075 hal ini menunjukan bahwa Rekening Dormant dan DPK berpengaruh 7.5\% terhadap laba dan sisanya $92.5 \%$ dipengaruhi oleh variabel lain yang tidak dimasukkan dalam penelitian.

Berdasarkan wawancara dari Bapak Toni Budi Kartono sebagai Kepala Departemen Consumer Banking di Bank Syariah Mandiri Kantor Pusat, menyatakan bahwa "rekening dormant yang terkena biaya akan mempengaruhi laba bank karena jumlah saldo di atas ketentuan saldo minimum sehingga saldo tersebut akan terpotong secara otomatis sebagai biaya administrasi." Oleh karena itu rekening dormant yang memiliki saldo di atas minimum akan tetap menjadi sumber pendapatan bank."

Hasil penelitian sebelumnya yang dilakukan oleh Ainul Hilda menjelaskan bahwa dengan mengaktifkan rekening dormant yang bersaldo dapat berpengaruh terhadap peningkatan pertumbuhan dana. Jika pertumbuhan dana meningkat maka laba bank pun mengalami peningkatan. Akan tetapi dari hasil penelitian menunjukkan bahwa rekening dormant tidak berpengaruh terhadap laba bank karena setiap kenaikan 1\% maka laba akan mengalami penurunan sebesar 0.022. Rekening dormant juga memiliki nilai $t_{\text {hitung }} 1.374$, oleh karenanya $t_{\text {hitung }}<t_{\text {tabel }}(1.374<2,026)$, sehingga tidak terdapat pengaruh yang signifikan rekening dormant terhadap variabel terikat Laba.

Dari hasil penelitian sebelumnya yang dilakukan oleh Wndiani Putri menjelaskan bahwa dana pihak ketiga (DPK) berpengaruh signifikan terhadap laba bank karena dana pihak ketiga merupakan komposisi dana yang paling besar dan berpengaruh terhadap kegiatan operasional bank. Jumlah dana pihak ketiga (DPK) meningkat maka laba pun akan meningkat karena terdapat pemasukkan dari dana pihak ketiga (DPK) yaitu giro, tabungan dan deposito yang berasal dari masyarakat. Tanpa adanya dana pemasukan, maka bank tersebut tidak dapat berfungsi baik dalam hal menghimpun dana, menyalurkan dana dan memberikan jasa yang akan berpengaruh terhadap laba. Berdasarkan hasil yang penulis teliti menunjukkan bahwa dana pihak ketiga (DPK) 
berpengaruh terhadap laba. Jika dana pihak ketiga (DPK) mengalami kenaikan 1\% maka laba bank akan meningkat sebesar 0.012. Dana Pihak Ketiga (DPK) memiliki nilai $t_{\text {hitung }}>t_{\text {tabel }}(2.244>2.026)$ dan Probability value dengan tingkat (sig) Dana Pihak Ketiga (DPK) 0.031 nilai $\alpha$ (derajat signifkansi) 0.05 artinya $0.031<0.05$ atau terdapat pengaruh yang signifikan antara Dana Pihak Ketiga (DPK) terhadap variabel terikat Laba.

Fitri dan Yulianti (2012) menyatakan bahwa terdapat beberapa faktor yang menyebabkan nasabah rekening giro pasif pada Bank Syariah Mandiri Cabang Pekanbaru, yaitu: Pertama, 21.8\% karena alasan kesibukan; Kedua, 50\% karena produk bank lain memudahkan; Ketiga, 12.5\% mempunyai banyak rekening; Keempat, 15.6\% karena lokasi usaha jauh dari cabang BSM. Upaya peningkatan edukasi produk giro BSM diharapkan dapat mengatasi salah satu faktor penyebab nasabah rekening giro pasif yaitu nasabah merasa bahwa produk giro bank lain lebih memudahkan bertransaksi dengan rekanan bisnis.

Rekening pasif (rekening dormant) ini erat kaitannya dengan tingkat loyalitas nasabah, semakin besar rekening dormant dari suatu bank menunjukkan tingkat loyalitas dari bank tersebut belum maksimal. Oleh karenanya pihak Bank Syariah Mandiri perlu melakukan berbagai inovasi produk untuk meningkatkan loyalitas nasabah kepada pihak bank, sehingga jumlah rekening pasif akan semakin menurun.

Stewart (1998) menyatakan bahwa hubungan dengan bank ditandai dengan ditutupnya akun utama yang ada. Bentuk mengakhiri hubungan ini dapat bervariasi, nasabah ada yang langsung meninggalkan begitu saja rekeningnya dengan meninggalkan sisa uang yang tidak berarti dan tidak ada transaksi ke depan, sehingga rekeningnya akan menjadi rekening pasif. Atau nasabah ada yang secara resmu mengakhiri kontrak dengan bank dan menutup rekening. Hubungan yang berakhir ini mungkin saja sebagai tanda telah terjadinya peralihan konsumen, dimana ia berhenti menggunakan rekening bank tersebut dan beralih dengan menggunakan 
rekening di bank lain, fenomena ini biasanya dikenal dengan customer switching.

Pursetyaningsih (2008) menyatakan bahwa keinginan nasabah untuk berpindah bank (customer switching) dipengaruhi oleh faktor harga dan rekomendasi oleh pihak lain. Sedangkan faktor reputasi bank, promosi, kualitas pelayanan, dan keterpaksaan berpindah tidak berpengaruh terhadap sikap atau niat nasabah untuk berpindah bank. Perilaku nasabah berpindah bank dipengaruhi pula oleh adanya pengalaman masa lalu dan kebiasaan nasabah yang mencoba produk atau bank baru. Oleh karenya perbankan harus mempertimbangkan faktor harga, kualitas pelayanan, dan rekomendasi pihak lain dalam mempertahankan nasabahnya dan menurunkan tingkat perpindahan nasabah.

Salah satu hal yang dapat dilakukan untuk menahan nasabah agar tidak berpindah bank, dan sebagai upaya menurunkan jumlah rekening pasif (rekening dormant) ialah dengan menerapkan customer relationship management (CRM). Sanjaya, dkk (2015) melakukan penelitian yang bertujuan untuk menganalisis hubungan antara CRM yang diukur melalui persepsi nasabah dengan tingkat loyalitas nasabah. Hasil yang didapat menunjukkan bahwa antara CRM dan loyalitas, aspek proses bisnis yang paling memengaruhi ialah frekuensi dan monetary, kemudian diikuti dengan aspek teknologi yang mempengaruhi monetary. Aspek orang (people) tidak memengaruhi tinggi atau rendahnya nilai RFM. Semakin loyal nasabah, maka semakin tinggi persepsi penilaian pada bank yang dilihat dari aspek orang, proses, dan teknologi.

Oleh karenanya untuk menurunkan jumlah rekening pasif dan meningkatkan loyalitas nasabah, pihak bank harus melakukan berbagai macam kebijakan yang mampu mendorong peningkatan jumlah dana pihak ketiga di bank syariah. Beberapa kebijakan yang dapat ditempuh ialah: meningkatkan kualitas pelayanan bank, meningkatkan jumlah produk dan variasi bank, dam selain itu meningkatkan promosi dan berbagai program yang menarik seperti 
souvernir pada saat pembukaan rekening atau bebas biaya administrasi ketika bertransaksi di mesin ATM bank lain.

Perbaikan kualitas layanan ini diharapkan akan mampu meningkatkan loyalitas nasabah bank, sehingga diharapkan dengan loyalitas yang semakin meningkat akan mampu menurunkan rekening pasif. Rekening pasif yang semakin menurun akan menjadikan jumlah dana pihak ketiga meningkat yang selanjutnya akan mampu meningkatkan pembiayaan, dan pada akhirnya akan mempengaruhi atau menaikkan jumlah laba pada pihak bank. Jumlah laba yang semakin meningkat akan mampu menaikkan modal inti bank, dan selanjutnya akan mampu menaikkan rasio kecukupan modal dari bank bersangkutan. Oleh karenanya penting sekali untuk segera dilakukan berbagai kebijakan terkait rekening pasif (dormant) pada bank syariah.

Salah satu hal yang merupakan kelemahan dari bank syariah ialah terkait dengan inovasi produk dan jaringan kantor. Hal ini menjadikan banyak nasabah yang menjadikan rekening di bank syariah hanya sebagai rekening sekunder saja dan bukan rekening utama ketika mereka melakukan transaksi. Bank syariah tidak lagi hanya bisa mengandalkan semangat syariah saja, tetapi pelayanan dan hal-hal lain yang terdapat di bank harus selalu ditingkatkan. Pasar nasabah yang memilih bank syariah karena faktor syariah tidaklah terlalu banyak, justru jumlah nasabah terbesar ialah nasabah rasional yang dapat dengan mudahnya berpindah bank apabila ada faktor-faktor yang menurut mereka tidak mampu dipenuhi oleh bank syariah.

\section{SIMPULAN}

Penelitian ini menunjukkan bahwa rekening dormant (rekening pasif) tidak mempengaruhi tingkat keuntungan pada Bank Syariah Mandiri, sedangkan hal yang mempengaruhi tingkat keuntungan dalam penelitian ini hanya dana pihak ketiga. Pihak Bank Syariah Mandiri secara aktif harus menurunkan jumlah rekening dormant, jumlah rekening dormant yang semakin menurun akan mampu menaikkan jumlah dana pihak ketiga. Pada akhirnya kenaikan jumlah dana pihak ketiga ini akan mampu menaikkan tingkat keuntungan bank. Namun nilai koefisien determinasi yang terlalu kecil 
menunjukkan bahwa masih banyak variabel yang mempengaruhi tingkat keuntungan belum dimasukkan ke dalam model ini.

Berdasarkan hasil analisis dan pembahasan pada penelitian ini, maka penulis memberikan saran-saran sebagai berikut: Pertama, Bank Mandiri Syariah harus terus meningkatkan kualitas kinerja agar tetap bersaing di perbankan syariah. Kedua, Bank Mandiri Syariah hendaknya meminimalisir rekening dormant dengan berbagai cara yang dapat meningkatkan jumlah DPK seperti membuat strategi dengan mensosialisasikan, mempromosikan, inovasi dan membuat produk-produk di Bank Mandiri Syariah sehingga nasabah tetap menabung di bank tersebut dan tidak melihat ke bank selain itu.

Keterbatasan dari penelitian ini ialah jumlah data yang hanya terfokus pada satu bank saja, sehingga jumlah data yang terkumpul hanya 40 data. Oleh karenanya pada penelitian selanjutnya, sebaiknya menambahkan jumlah bank dan/atau jumlah periode sehingga tingkat validitasnya lebih tinggi. Selain itu pada penelitian selanjutnya dapat menambahkan faktor-faktor yang mempengaruhi rekening dormant dan juga dapat melakukan riset penelitian bukan hanya pada satu bank melainkan dua atau lebih. Sehingga dapat membandingkan variabel dependent dan variabel independen antar bank.

\section{PUSTAKA ACUAN}

Al Arif, M.N.R. 2015. Pemasaran Stratejik pada Asuransi Syariah. Jakarta: Gramata Publishing

Antonio, M.S. 2001. Bank Syariah dan Teori ke Praktik. Jakarta : Gema Insani Press.

Arifin, Z. 2005. Sejarah Perkembangan Perbankan Syariah. Jakarta: Rajawali Pers.

Arikunto, S. 2006. Prosedur Penelitian Suatu Pendekatan Praktik. Jakarta: PT Rineka Cipta.

Ascarya. 2007. Akad Dan Produk Bank Syariah. Jakarta : PT Raja Grafindo Persada. 
Bungin, B. 2010. Metodologi Penelitian Kuantitatif: Komunikasi, Ekonomi dan Kebijakan Publik, serta Ilmu-ilmu Sosial lainnya. Jakarta: Kencana.

Firlandari, M. 2011. Pengaruh Dana Pihak Ketiga (DPK) dan Pertumbuhan Penyaluran Kredit terhadap Non Performing Loan (NPL). (Skripsi Tidak Dipublikasikan). Jakarta: UIN Syarif Hidayatullah Jakarta.

Fitri, K \& R. Yulianti. 2012. Tinjauan Faktor Penyebab Domant Account (Studi Kasus Bank Syariah Mandiri Cabang Pekanbaru). Jurnal Ekonomi, Vol. 20, No. 4, hlm. 1 - 17.

Gunawan. 2010. Ekonomi Mikro. Kudus: Nora Media Enterprise.

Hasan, A. 2010. Marketing Bank Syariah. Bogor: Ghalia Indonesia.

Hilda, A. 2006. Peningkatan Fee Base Administrasi Tabungan Dengan Mengaktifkan Dormant Account Bersaldo Melalui Telemarketing Dan Kunjungan Ke Nasabah: Studi Kasus Pada Pt Bank Mandiri Syariah KC Tangerang. (Skripsi Tidak Dipublikasikan). Jakarta: Universitas Trisakti

Ismail. 2011. Perbankan Syariah. Jakarta: Kencana.

Karim, A.A . 2010. Analisis Fiqih dan Keuangan . Jakarta: PT Raja Grafindo Persada.

Kasmir. 2003. Dasar-Dasar Perbankan. Jakarta: PT Raja Grafindo Persada.

Morissan. 2010. Periklanan Komunikasi Pemasaran Teradu. Jakarta: Kencana.

Pursetyaningsih. 2008. Pengaruh Harga, Reputasi, Kualitas Jasa, Promosi, Keterpaksaan Berpindah, dan Rekomendasi Pada Perilaku Nasabah Berpindah Bank. Jurnal Manajemen Teori dan Terapan, Volume 1, No. 2, hlm. 186-208.

Sanjaya, R. dkk. 2015. Hubungan Customer Relationship Management dengan Loyalitas Nasabah (Studi Kasus: PT Bank 
XYZ Cabang Bogor). Manajemen IKM, Vol. 10, No. 2, hlm. 151162

Stewart, K. 1998. An Exploration of Customer Exit in Retail Banking. International Journal of Bank Marketing. Vol. 16, No. 1, hlm. 6 - 14. 